\title{
Osteotomies Around the Knee
}

Editors

ANNUNZIATO (NED) AMENDOLA

DAVIDE EDOARDO BONASIA

\section{CLINICS IN \\ SPORTS MEDICINE}

www.sportsmed.theclinics.com

Consulting Editor

MARK D. MILLER

July 2019 • Volume 38 • Number 3 